\title{
Measuring the Quality of Life in the Workplace (QLW) Through Job Diagnostic Survey (JDS): Comparative Study on Two Legal Nature Differentiated Organizations
}

\author{
Luiz Augusto de Carvalho Francisco Soares, Afrânio de Amorim Francisco Soares Filho, \\ Luis Cláudio de Jesus Silva, Aristides da Rocha Oliveira Junior, Ricardo Jorge da Cunha Costa Nogueira, \\ Paulo César Diniz de Araújo \\ Universidade Federal de Minas Gerais, Belo Horizonte, Brazil
}

\begin{abstract}
The article presents a theoretical-empirical reflection about concepts, models, and practices of Quality of Life at Work (QLW) in organizations of different legal nature. The initial proposition of the research suggested that private organizations, that are more susceptible to competitive pressures in the market for resources and the uncertainties regarding the employability tend to have worse indicators of QLW than the public organizations that exhibit greater control over their influx of resources and greater stability in jobs that are offered. The literature review included the concepts and models of QLW as well as the characteristics and application methodology of the Job Diagnostic Survey (JDS), and your score on Task Motivational Potential (TMP), as instruments of evaluating the dimensional indicators of QLW in organizations. In methodological terms, we proceeded to a multiple case study comparative, supported by the application of the reduced version of JDS, through its questionnaire that has already been validated in previous studies in two organizations, a private foundation supporting university and a public company of electricity supply, both located in the State of Amazonas-Brazil. The research findings using the JDS instrument indicated failed to detect significant differences between the scores of TMP between the two organizations, nor any robust correlation between their respective legal personalities and environments of institutional performance. Nevertheless, the small differences found suggest a framework of indicators of QLW slightly more favorable to the foundation of university support.
\end{abstract}

Keywords: quality of life, employability, private foundation, public company, Amazonas-Brazil

Luiz Augusto de Carvalho Francisco Soares, Doctoral candidate, Administração Department, Universidade Federal de Minas Gerais.

Afrânio de Amorim Francisco Soares Filho, Doctoral candidate, Administração Department, Universidade Federal de Minas Gerais.

Luis Cláudio de Jesus Silva, Doctoral candidate, Administração Department, Universidade Federal de Minas Gerais.

Aristides da Rocha Oliveira Junior, Doctoral candidate, Administração Department, Universidade Federal de Minas Gerais.

Ricardo Jorge da Cunha Costa Nogueira, Doctoral candidate, Administração Department, Universidade Federal de Minas Gerais.

Paulo Cesar Diniz de Araújo, Doctoral candidate, Administração Department, Universidade Federal de Minas Gerais.

Correspondence concerning this article should be addressed to Luis Cláudio de Jesus Silva, Rua Eduardo Ribeiro, 417, São Francisco. CEP: 69.305-140, Boa Vista, Roraima, Brasil. E-mail: luisclaudiojs@gmail.com. 


\section{Introduction}

The widespread practice of Quality of Life at Work (QLW) in organizations both public and private is a relevant phenomenon in the last three decades of the century. And early 20th century XXI, on a global scale. The controversy around the conceptual theme, as well as mismatches between the QLW as theoretical ideas and as a set of management practices empirically observed (Ferreira, Alves, \& Tostes, 2009) demand, however, the need to deepen the role of variables/dimensions exogenous to the current models for measuring QLW in determining its effectiveness.

An example of exogenous variable to the models of QLW, the subject of research, would be the type of legal organization where QLW is measured by indicators, whether public (government agencies of the direct administration, local authorities, Non-governmental organizations (NGOs), and foundations maintained with public funds, etc.) or private (companies and private legal entities). The theoretical proposition that supports the research of this variable relates to the fact that different types of organization are subject to environmental challenges and pressures of various kinds—some types of companies and private NGOs compete for customers and market resources through the regulatory mechanism price system, the organizational structure of the industry and the scope of the strategies used; public organizations state or non-state actors compete for resources of another order as institutional legitimacy in public policy processes and with civil society, budgetary allocations, etc., are more stable over time, because their existence or continuation is directly threatened by contingencies market (Oliveira Jr., 2002; Serra, 2006).

Due to this differentiation of challenges and environmental pressures, their environments for work tasks as well as motivational factors relating to the performance of these tasks may be impacted, be also different. How does this impact the formulation and measurement of QLW in different types of organization? This text aimed to face this cognitive challenge on an exploratory mode, through a literature review of the concepts and models of QLW, carried out in section two, is the views of the literature to model the Job Diagnostic Survey(JDS), in section three, and its empirical application (as described in sections four-methodological notes and section five-empirical research) as a tool for gathering indicators of QLW in two legally different organizations, both located in the Amazon-Brazil: a private foundation supported by a university and a provider of public electricity company. The results of this comparative study are presented and discussed further in section five, it is followed by a final section containing conclusions and recommendations.

\section{Theoretical Propositions and Models on QLW}

\section{The Historical and Contextual Assumptions of QLW}

According to Sant'Anna, Kilimnik, and Moraes (2011), the movement around the QLW is due to the instrumental and theoretical systematization of a concern that pervades the history of human labor, with special emphasis from the phenomenon of industrial society, in the context of the first Industrial Revolution and, more particularly, since the foundation of scientific principles of bureaucratic management oriented to modern private and public organizations, with Weber, Taylor, Fayol, etc., these same researchers outline a path context-historical in which the assumptions are part of the development of the principles and models of QLW under administrative theories. Table 1 summarizes this path constructed by the authors of the literature review. 
Table 1

Historical-Contextual Presuppositions of the Insertion of $Q L W$ in Theories of Administration

\begin{tabular}{|c|c|c|}
\hline Historical context & Administrative theory & QLW presupposition \\
\hline $\begin{array}{l}\text { The second Industrial Revolution } \\
\text { (the middle of the 19th century) }\end{array}$ & $\begin{array}{l}\text { - Marxist theory of } \\
\text { capitalist enterprises. }\end{array}$ & $\begin{array}{l}\text { - Trade unions' fight for subsistence conditions, increase of } \\
\text { salaries, safety, accident prevention, achievement of social } \\
\text { security and retirement, through labor and social policies. }\end{array}$ \\
\hline $\begin{array}{l}\text { Taylorism and Fordism (the first } \\
\text { quarter of the 20th century) }\end{array}$ & 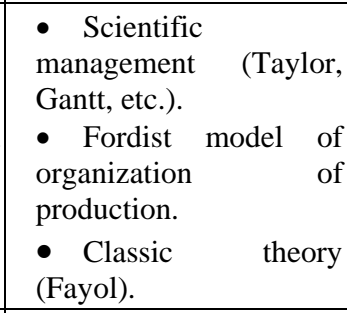 & $\begin{array}{l}\text { - Priority to capitalist prosperity, which would positively } \\
\text { affect the remuneration of workers. } \\
\text { - Incentives on salary. } \\
\text { - Profit sharing. } \\
\text { - Administrative efficiency. } \\
\text { - Widespread dissatisfaction of the working class, } \\
\text { promoting reactions such as absenteeism, strikes, sabotage, } \\
\text { etc.. }\end{array}$ \\
\hline Hawthorne experiments (1930s) & $\begin{array}{l}\text { - School of human } \\
\text { relations (Mayo). }\end{array}$ & $\begin{array}{l}\text { - } \quad \text { Rewards for productivity. } \\
\text { - } \text { Effect of physical environment on productivity. } \\
\text { - } \text { Recognition of the social worker. } \\
\text { - } \quad \text { Training. } \\
\text { - } \text { Participation. } \\
\text { - } \text { Group moral. }\end{array}$ \\
\hline $\begin{array}{l}\text { Heyday of mass society (1950-1960 } \\
\text { decades) }\end{array}$ & $\begin{array}{l}\text { - Behavioral theories } \\
\text { (Maslow, Herzberg, } \\
\text { McGregor). } \\
\text { - Theory of open } \\
\text { systems. }\end{array}$ & $\begin{array}{l}\text { - Attendance answering hierarchical human needs: } \\
\text { physiological, safety, social, and self-esteem. } \\
\text { - Hygienic factors (= basic needs at work) and motivational } \\
\text { (= those that meet the individual development of their own } \\
\text { work). } \\
\text { - Principle of enrichment position (job enrichment). } \\
\text { - Contraposition of Y Theory (= individual can be } \\
\text { motivated to work creatively) about Theory X (= individual } \\
\text { indolent, dependent on direction, without initiative and } \\
\text { focused only on safety). } \\
\text { - Work of the individual affected by system factors external } \\
\text { to the organization (society, culture, politics, etc.). }\end{array}$ \\
\hline $\begin{array}{l}\text { Crisis of mass } \\
\begin{array}{l}\text { Taylorism-Fordism } \\
\text { decades })\end{array}\end{array}$ & $\begin{array}{l}\text { - Contingency theory } \\
\text { (socio-technical } \\
\text { approach of the } \\
\text { Tavistock Institute). } \\
\text { - QLW concept of } \\
\text { Louis Davis } \\
\text { - Japanese model } \\
\text { (Toyotism). }\end{array}$ & $\begin{array}{l}\text { - Movimento civil rights movement. } \\
\text { - Structuring of the principles of corporate social } \\
\text { responsibility. } \\
\text { - } \text { Crisis oil. } \\
\text { - Interaction between production technologies and work } \\
\text { organization model. } \\
\text { - Searching for self-fulfillment at work and outside it. } \\
\text { - Encourage self-development and creativity. } \\
\text { - } \text { Flexibility in work schedule. } \\
\text { - } \text { Establishment of semi-autonomous groups and QCC. } \\
\text { - } \text { Reaction to the } 1980 \text { s workaholic model. }\end{array}$ \\
\hline
\end{tabular}

Note. Source: Adapted from Sant'Anna et al. (2011).

Stands out in this trajectory, the evolution of a general principle of political-ideological (realized in the fight for better working conditions) to a concept and set of practices of management nature embedded in organizations, both private and public, since the last quarter of the 20th century. The Programs of Quality of Life at Work (PQLW) and the proposed QLW versification of the various work environments (such as the JDS model, the subject of discussion, and application in the screen text) proliferate as institutionalized organizational practices so legitimized in the frames of both the intensification of capitalist competition on a global scale which affects 
mainly private companies and NGOs that compete for funding from third parties, as of the fiscal crisis of governments of the developed and developing countries (after the oil shocks of the 1970s, the crisis of debt of several emerging nations, etc.), which required adjustments in fiscal policies and the adoption of management models guided by the flexibility of labor relations in the public sector and the tightening of instruments for assessing the performance of public employees.

Both frameworks entail challenges and pressures in their work environments of public and private organizations that require the adoption of policies and compensatory programs that create a chance of a re-signification of the work performed by the employee (private or public) and a possible integration of work and life of the individual in a qualitatively positive way (Ferreira et al., 2009).

\section{Concepts and Models of QLW}

Common points to all definitions of QLW is the reaction to the rigors of Taylorism and the consequent goal of humanizing the work, increase the well-being and participation of workers in organizations. According to Sant'Anna et al. (2011):

... The key elements of QLW specifically rely on four pillars: (1) solving problems involving members of the organization at all levels (participation, suggestions, and innovations); (2) restructuring the basic nature of the work (enrichment tasks, job redesign, job rotation, autonomous, or semi-autonomous groups); (3) innovation in the system of rewards (financial and non-financial remuneration); (4) improving the work environment (climate, culture, physical environment, ergonomics, and health care). (p. 11)

QLW should not label programs and actions guided by mere marketing or public relations, or just improvements extrinsic conditions to work, because it dispenses the greater involvement of employees, participation, autonomy, feedback, etc. (Vasconcelos, 2001).

In Table 2, we present a summary of this literature review of models, the authors raised and point their groups of dimensions/variables focused.

Table 2

Models of $Q L W$

\begin{tabular}{|l|l|}
\hline Authors & Model/dimension/variable component \\
\hline & $\begin{array}{l}\text { Criteria for QLW: } \\
\text { (1) Fair and adequate compensation: income, equity, foreign, and domestic. } \\
\text { (2) Health and safety in working conditions: working hours, physical environment safe, and healthy. } \\
\text { (3)Developing skills: autonomy, task identity and meaning, skills, and feedback. }\end{array}$ \\
(1973) & $\begin{array}{l}\text { (4) Future opportunities for professional growth: career, professional growth, and job security. } \\
\text { (5) Social integration in the organization: adequate opportunities, relationships, and sense of community. } \\
\text { (6) Constitutionalism: respect for law and labor rights, personal privacy, freedom of expression, and rules/routines. } \\
\text { (7) Work and total space of life: role in balancing the work life of the employee. } \\
\text { (8) Social relevance of work: image, social responsibility services, and employees. }\end{array}$ \\
\hline $\begin{array}{l}\text { Bimensions for analysis QLW: } \\
\text { (1973) }\end{array}$ & $\begin{array}{l}\text { (1) The work itself: creativity, variability, autonomy, involvement, and feedback. } \\
\text { (2) Personal and professional growth: training, growth opportunities, relationship at work, and organizational roles. } \\
\text { (3) Meaningful tasks: tasks complete, increased responsibility, rewards financial/non-financial, and enrichment. } \\
\text { (4) Functions and structures open: climate and creativity, transfer goals. }\end{array}$ \\
\hline $\begin{array}{l}\text { Turner and } \\
\text { Lawrence } \\
\text { (1973) }\end{array}$ & $\begin{array}{l}\text { (1)Autributes of focus on tasks in relation to the satisfaction with work and levels of absenteeism: } \\
\text { (2) Interaction required. } \\
\text { (3) Interaction optional. } \\
\text { (4) Knowledge/skills required. } \\
\text { (5) Responsibility. }\end{array}$ \\
\hline
\end{tabular}


(Table 2 continued)

\begin{tabular}{|c|c|}
\hline Authors & Model/dimension/variable component \\
\hline $\begin{array}{l}\text { Hacl } \\
\text { and } \\
(197\end{array}$ & $\begin{array}{l}\text { JDS > dimensions of job creating psychological states critical to performance of work: } \\
\text { (1) Variety of skills (VS): degree to which the job requires a variety of different activities for its implementation } \\
\text { through the involvement and use of various skills/talents by the individual. } \\
\text { (2) Identity of task (IT): degree to which the task requires the execution of a work "full” and identifiable performed } \\
\text { from start to finish in order to obtain visible results. } \\
\text { (3) Meaning of task (MT): degree to which the job has a substantial impact on the lives or work of others, whether } \\
\text { they belong to the organization or external environment. } \\
\text { (4) Autonomy (AU): degree to which the job provides the individual substantial independence and freedom to } \\
\text { schedule your work and determining the procedures in their implementation. } \\
\text { (5) Extrinsic feedback (EF): degree to which the individual receives clear information about their performance by } \\
\text { their superiors, colleagues, or clients. } \\
\text { (6) Feedback own work (FOW): degree to which the actual performance of work activities provides direct and clear } \\
\text { information about their performance. }\end{array}$ \\
\hline $\begin{array}{l}\text { Lipp } \\
\text { (197 }\end{array}$ & $\begin{array}{l}\text { Dimensions of QLW: } \\
\text { (1) The work itself: performance feedback, clear work objectives, controls reduced, greater responsibility, and } \\
\text { greater participation decisions. } \\
\text { (2) The individual: self-image, learning, friendship, consistency between work and life goals. } \\
\text { (3) The production work: greater responsibility, intergroup collaboration, and complete work units, rewards for } \\
\text { quality and innovation, measurable objectives. } \\
\text { (4) Functions and structure of the organization: climate conducive to creativity, two-way communication, respect } \\
\text { for the individual, organizational development and advancement. }\end{array}$ \\
\hline DeI & $\begin{array}{l}\text { physical infrastructure work: } \\
\text { evention of problems in the physical work environment, specifically: heat, noise, vibration, and } \\
\text { orevention programs: } \\
\text { d ease of identifying your results by workers and trade unions; } \\
\text { credibility of the employees in relation to the company; } \\
\text { ialog that such programs established between employees, unions, and companies. }\end{array}$ \\
\hline $\begin{array}{l}\text { We } \\
\text { (19 }\end{array}$ & $\begin{array}{l}\text { rofits, and productivity agreements. } \\
\text { vorkers' councils. } \\
\text { roups. }\end{array}$ \\
\hline & $\begin{array}{l}\text { Compensation as a factor of QLW compensation involves: } \\
\text { (1) Economic transaction: individuals are a factor of production in secondary plan. It is exclusively monetary factors. } \\
\text { (2) Transaction psychological: represents the compensation for the employee's psychological contract established } \\
\text { with the organization (= certain behaviors and attitudes in exchange for a salary, benefits, and other reasons). The } \\
\text { focus is directed to the individual and their relationship with the organization. } \\
\text { (3) Transaction sociological: the focus is on the interaction between the individual and organization within a } \\
\text { specific cultural environment. } \\
\text { (4) Transaction policy: compensation is defined as the resultant of forces of social factors involved (the } \\
\text { organization itself, unions, individuals, etc.). The greater the power of each of these elements, the greater the } \\
\text { possibility of changes occur in your benefit. } \\
\text { (5) Transaction ethics: inserted in all matters relating to remuneration, since it represents a dependency relationship } \\
\text { with morality and justice. The remuneration is perceived from the principles of equality, legality, distributism, or } \\
\text { satisfaction of individual needs. }\end{array}$ \\
\hline & $\begin{array}{l}\text { Success factors of QLW: } \\
\text { (1) Perceived needs. } \\
\text { (2) Focus of the problem highlighted in the organization. } \\
\text { (3) Framework for identifying and resolving the problem (= theory/model training process and participants). } \\
\text { (4) Compensation designed to process and outcome. } \\
\text { (5) Multiple systems affected. } \\
\text { (6) Wide involvement of the organization. } \\
\text { (7) Consideration of the various levels of application development projects. } \\
\text { (8) Changes in the management system and management structure. } \\
\text { (9) Changes in top management behavior. } \\
\text { (10) Theoretical foundation and roadmap to support the participants in the examination and understanding of } \\
\text { issues. }\end{array}$ \\
\hline
\end{tabular}


(Table 2 continued)

\begin{tabular}{|l|l|}
\hline Authors & Model/dimension/variable component \\
\hline $\begin{array}{l}\text { Nadler and } \\
\text { Lawler } \\
\text { (1983) }\end{array}$ & $\begin{array}{l}\text { (11) Structured processes for troubleshooting. } \\
\text { (12) Training participants. } \\
\text { (13) Understandings built over processes, based on the results of the activities of QLW. }\end{array}$ \\
\hline $\begin{array}{l}\text { Werther and } \\
\text { Davis (1983) }\end{array}$ & $\begin{array}{l}\text { Factors affecting QLW: } \\
\text { (1) Organizational: purpose, objectives, organization, departments, offices, and activities. } \\
\text { (2) Environmental: social, cultural, historical, competitive, economic, government, and technology. } \\
\text { (3) Behavioral needs HR, motivation, and satisfaction. }\end{array}$ \\
\hline $\begin{array}{l}\text { Huse and } \\
\text { Cummings } \\
\text { (1985) }\end{array}$ & $\begin{array}{l}\text { (1) Factors of QWL: participation, design positions, innovation reward system, and improvement of the } \\
\text { organizational environment. } \\
\text { (2) Impacts on QLW: communication, motivation, and empowerment. }\end{array}$ \\
$\begin{array}{l}\text { Moraes and } \\
\text { Kilimnik } \\
\text { (1994) }\end{array}$ & $\begin{array}{l}\text { Motivational potential of task (PMT)-score adapted from Hackman and Oldham (1975) and includes all } \\
\text { dimensions of the task, plus two more: } \\
\text { (1) Personal and work outcomes. } \\
\text { (2) Contextual satisfactions. }\end{array}$ \\
\hline
\end{tabular}

Note. Source: Adapted from Sant'Anna et al. (2011).

Despite the models of QLW having advanced significantly, covering so extensive and detailed multiple dimensions and variables that affect the individual's relationship with their work, have not yet held the intent to erect a definitive construct (Sant'Anna et al., 2011). This is because the objective dimensions that affect the perception of individuals and groups on the qualitative aspects of the work are modified and acquire dynamic nuances, as the context and the specific social, cultural, and psychological personal/collective.

The quality of any phenomenon is by nature a subjective perception (dependent on the psyche of the individual and their values) and inter-subjective (social relationships influence on individual perception). This applies to a product purchased, a work of art, and working conditions. The management of the organization can be successful or not attempting to influence this perception, offering a range of formal and informal tools of motivation, safety, awards, benefits, performance feedback, autonomy, infrastructure, etc.. The success of these interventions appears to be linked to factors and multivariate contingent on the social history and profile of employees. Such complexity, as also suggested by Sant'Anna et al. (2011), can only be faced on a scientifically way more robust to: (1) questioning the depth of socio-political-cultural involving the operation of the organization and relationships interpersonally and inter-organizationally; (2) overcoming the elitism that still involves approaches to QLW (QLW sense of the perspective of individuals); and (3) the integration of research methods' quantitative and qualitative dimensions can reveal non-perceived the models already constructed and adopted.

\section{Measuring QLW in Public and Private Organizations Through the JDS}

Under the proposed measurement of QLW indicators summarized in the previous section, we highlight the measuring instrument titled JDS prepared by Hackman and Oldham (1975). In this classic work in the field of organizational behavior, these authors present and discuss: (1) the conceptual basis of the instrument; (2) the characteristics of the instrument itself; (3) the empirical properties of the instrument; and (4) the uses and limitations of the instrument. The authors point to the fact that JDS was not designed as a tool for design/redesign of tasks aimed at raising their motivational potential, but for the diagnosis of motivational properties of work done by individuals and research and evaluation activities/tasks already redesigned. It constitutes, therefore, more a research tool and advice on cognitive planning work than planning labor itself (Hackman \& Oldham, 1975).

Regarding the theoretical basis, the JDS stems from a previous model of Hackman and Lawler (1971), 
which established a set of relational connections between three major theoretical categories, referred to as “critical psychological states”-significance experienced labour responsibility, experienced results for work and knowledge, results for activity of labour - and that determine personal and professional positive results as high internal motivation, great job satisfaction, high-quality performance, and low levels of absenteeism and turnover. The three Critical Psychological States are thus defined by the researchers Hackman and Oldham (1975):

Experienced the significance of the labor-the extent to which the employee experiences the work, generally as significant, valuable, and meritorious.

Responsibility experienced by the results of the work - the degree to which the employee feels personally responsible for the results of the work he or she performs.

Knowing the results - the extent to which the employee knows and understands, on a continuous basis, how effectively he or she performs the work. (p. 162)

Each of these components is a theoretical construct measured by one or more of seven indicators, called “central labor dimensions” (core job dimensions), the following described by Sant’Anna et al. (2011):

VS: degree to which the job requires a variety of different activities for its implementation through the involvement and the use of various skills/talents of the individual.

IT: degree to which the task requires the execution of a work "full” and identifiable performed from start to finish in order to obtain visible results.

MT: degree to which the job has a substantial impact on the lives or work of others, whether they belong to the organization or external environment.

AU: degree to which the job provides the individual substantial independence and freedom to schedule your work and determining the procedures in their implementation.

EF: degree to which the individual receives clear information about their performance by their superiors, colleagues, or clients.

FOW: degree to which the actual performance of work activities provides direct and clear information about their performance.

Inter-relationship (IR): degree to which the job requires the employee to deal directly with people, including customers. (pp. 24-25)

The connections between the three critical psychological components, the five dimensions of the work related to them and the results are expected labor described by Figure 1.

Regarding the characterization of the instrument itself, the JDS is the lynchpin potential motivational score (MPS), which provides the basis for quantifying the theoretical nexus established between the three critical psychological components and the five dimensions of the central work, the latter being the indicators of the same instrument. Equation (1) is created by the authors for the MPS (Hackman \& Oldham, 1975, p. 160):

$$
M P S=\left[\frac{V H+I T+S T}{3}\right](\text { AU. Feedback })
$$

The scores for the questions asked and pertinent to each of the dimensions of the task are measured on scales ranging 1-7, and 1 corresponding to the lower degrees of the scale (e.g., "very little”, "rarely”, etc.), and 
7 is the greatest degree of intensity of the same scale (e.g., "pretty", "often", etc.). Note that the scores on the first three dimensions are measured through a simple arithmetic mean, being correlated to the same state psychological critical ("significance experienced labor"), properly weighted by the impact of the other two dimensions, correlated to the other two components.

\begin{tabular}{|c|c|c|}
\hline $\begin{array}{l}\text { Central dimensions of } \\
\text { work }\end{array}$ & $\begin{array}{l}\text { Critical psychological } \\
\text { components }\end{array}$ & $\begin{array}{l}\text { Personal } \\
\text { results }\end{array}$ \\
\hline
\end{tabular}

Variety of skills (VH)
Identity of the task (IT)
Meaning of the task (ST) Eutonomy (AU) $\begin{aligned} & \text { Experienced significance } \\ & \text { of the labor } \\ & \text { Fesperienced by the the work } \\ & \text { Knowing the results of } \\ & \text { the work active }\end{aligned}$

Figure 1. Critical psychological components. Source: Adapted from Hackman and Oldham (1975, p. 161) and Sant'Anna et al.

(2011).

Moraes and Kilimnik (1994) (cf. Sant'Anna et al., 2011), working on the model of Hackman and Oldham, further compounded two dimensions of the task-results personal and work context satisfactions and redefining the name of the MPS to "potential motivational the task (PMT)" and changing its mathematical formula late in terms of weighting, etc., enhancements accepted and incorporated by Hackman and Oldham, according to the details described by Sant'Anna et al. (2011):

The first group was incorporated into the model by Hackman and Oldham in order to identify affective reactions or personal feelings that the individual gets to perform the work and deliver results as producing high-quality and low absenteeism and turnover. The variables that make up this group are: (1) Overall satisfaction with work-SG: global mean level at which the employee is satisfied with his work; (2) Internal motivation to work-MIT: degree of motivation, the individual experiences positive internal feelings when effectively performs its task, and negative internal feelings, when the causes poor quality; (3) Production of high quality work-MDT: degree to which work is produced considered high quality; (4) Absenteeism and turnover low-ABR: level of absence and staff turnover.

The second group, in turn, seeks to gauge the degree of well-being of the individual in relation to the satisfaction of the following requirements: SS—-satisfaction safety, SC—satisfaction with compensation, SCT—satisfaction with coworkers, SSU—satisfaction with supervision, SPC—satisfaction with possibility of growth. The model also presents another variable, called "need of individual growth"-NIG, which allows to identify the relationship between the characteristics of the task and the individual responses, as individuals come to the organization with different abilities and needs. Accordingly, when individuals have a high need for growth, creativity, challenge, among others, is very likely to respond more positively to jobs that offer more significance, responsibility and knowledge of results than when these needs are not high. The model, through the variable NIG incorporates this fact, showing that the relationship between task characteristics and individual responses are contingent to the growing needs of the individual (...). (p. 25)

The JDS of Hackman and Oldham, with the introduction of PMT and Moraes and Kilimnik thus allows 
reconceptualize in a more objective and measurable QLW, as follows: “(...) a resultant direct combination of basic dimensions of task capable of generating psychological states, in turn, result in motivation and satisfaction on different levels and in different attitudes and behavior” (Sant’Anna et al., 2011).

\section{Methodological Notes}

As for the type and method of research, and on weekends, this research is characterized by being explanatory, quantitative, field, multiple case study, comparative and descriptive. Explanatory, because it seeks to establish explanation to the phenomenon studied applied to populations chosen; quantitatively by using the JDS scale (1-7) for the tabulation of the data in order to obtain their results; count to have had an interview for the empirical application the standardized questionnaire and grouped the responses according to the previously established objectives, multiple case study (Yin, 2010) cover by a single unit of analysis in two cases, or two distinct populations; comparative, for having, as final premise, comparison of results between a public and private foundation and university support; descriptive, to present the characteristics of a given population/phenomenon or even establish relationship between variables.

The objective was to identify the factors that contribute in some way to improving the QLW employees and managers of the two organizations studied. The field is directly related to an empirical research carried out in organizations where phenomena occur under investigation. The comparative study of the cases sought to deepen the analysis and description, considering the changes in managerial function proposed in the literature, the changing organizational technologies in recent decades and the main sources of tension in the workplace that affect the managers of the organizations under study. These changes are responsible for providing a greater or lesser degree of QLW in the organizational environment.

This study has as the unit of analysis the QLW, centered on the measurement of the PMT score and, as a unit of observation, individuals who constitute the management levels of two organizations based in the state of Amazonas-Brazil. These organizations operate in different areas, with FMURAKI (Muraki Foundation), a foundation of Institutional Support and AM_ENERGIA University (Amazonas Energia), a federal public company with expertise in providing services in the electricity sector.

For data collection, we used the questionnaire JDS—reduced version, organized by Federal University of Minas Gerais (UFMG) researchers and adapted for use in academic environments. The instrument sought to detect the main factors impacting QLW in organizations surveyed, measuring quantitatively the degree scale formed by intensity score ranging from 1 (very unsatisfying) to 7 (very good).

Was applied a total of 82 questionnaires, 41 in each organization and, after treatment of the data was decided to exclude, for inconsistency and absent responses, three questionnaires. So the end of the base survey had 78 respondents, 41 of the FMURAKI and 30 of the AM_ENERGIA. The definition of the sample size was based on small populations (M. M. Hill, \& A. Hill, 2008), under the rules of thumb for simple analyses, which indicate the minimum size of a sample, from the assumption that the null hypothesis to be tested $\alpha=0.05$. Thus, it was used up the test for two independent samples that recommended for this type of study, a minimum size not less than 60 cases in total, or, as in this article, 30 in each sample. It is worth noting that if the two samples have different sizes, this should not be large in order to maintain balance.

The application was made on the spot and on a face, with prior appointment, sensitized by previous meeting with managers, aiming to explain the modus operandi of the data collection and request to join the search. Data collection occurred through the self-filling questionnaire with closed questions and scalar numeric 
scalar. The instrument contained the following sections: (1) consists of questions to be answered on a closed using a scale range 1-7, with 1 being "rarely" and 7 "often" to questions that investigated the interaction, autonomy, identification task objective, the variety of these, its significance, the binding orders and feedback to the performance of the individual; (2) which brought the scale indicated by the individual issues of how to appropriately statements describe your work; and (3) which investigated the degree of satisfaction of these individuals with their respective work.

The questionnaires were administered in paper format by physical, having been delivered to the respondents and accompanied by one of the researchers, who was present and next to answer any questions. After application of the instrument, the data were treated and processed with the aid of software and Excel Sphinx Eureka. For treatment of the results was descriptive analyzes as mean, minimum, maximum, median, and standard deviation, and correlation analysis by Principal Component Analysis (PCA) and Fisher's test for validation of the data obtained.

\section{Analysis of Results}

The results followed the guidelines of the method JDS, allowing the survey indices, which were later grouped into two analytical dimensions: core dimensions of job satisfaction and specific. Other dimensions of the JDS could not be reached due to limitations imposed by the restricted version of the collection instrument.

The set of core dimensions of work lists the factors that directly impact the motivation for the task, helping to better understand the work and attitudes of workers to develop it. The specific satisfactions, in turn, are part of the affective reactions and involve a range of factors that are essential to the existence of job satisfaction.

Table 3

Attributes for $Q L W$

\begin{tabular}{lll}
\hline & Central dimensions of the Labor & Specific satisfaction \\
\hline FMURAKI & 5.06 & 5.42 \\
AM_ENERGIA & 4.87 & 5.02 \\
Total & 4.97 & 5.23 \\
\hline
\end{tabular}

Notes. The values in the table are for each criterion and each category, the number of observations excluding non-responses; Results of Fisher's test, DIMENSIONS OF JOB: V_inter $=0.7$, V_intra $=0.3, F=2.4, p-1=87.8 \%$; satisfactions SPECIFIC: V_inter $=1.9$, V_intra $=0.8, F=2.4, p-1=88.1 \%$; ${ }^{a}$ An average of the averages of VH, IT, ST, AU, FI, FE, and IR; ${ }^{b}$ An average of the averages of SS, SC, SCT, SSU, and SPC. Source: Research data.

The results show a relative balance between enterprises surveyed and, with small but noticeable advantage for FMURAKI (5.06, 5.42). By JDS score, the FMURAKI evaluation of the dimensions of work, achieves a status of "satisfactory", while AM_ENERGIA reaches a status of "neutral". In specific satisfactions both are framed in the "satisfactory". In general it should be evaluated each criterion components of such sets, so that they can identify the factors that impacted positively or negatively.

Separately you can analyze it in FMURAKI among the main dimensions of the work (VS, IT, MT, FI, FE, and IR), those that had the highest rates (IR 6.0, with $5.83 \mathrm{MT}$ ) are well above the average of the other company (5.29). It can deduce that there is a robust level of impact of the work of individuals in your life and the work of others. Likewise, contact with other people in the course of work, including the relationship with members of external organizations and customers, contributing positively in the perception of the meaning of work in this organization. In contrast, it is clear that the work is not yet seen in a continuous, unfragmented (IT, 
4.70), partly explained by the limited autonomy of the function (AU, 4.72). Other variables with indices below the average were the feedbacks (EF 4.78 and IF 4.87), indicating that the level of obtaining direct feedback and goal supervisors and colleagues regarding their job performance are in a "neutral". Although the central dimensions of the task AM_ENERGIA, like the FMURAKI, got their best levels in ST (5.77) and IR (5.71), as well as the worst in IT (4.51) and AU (4.66). In this dimension the two organizations were very close to the results.

Table 4

Attributes for Correction of the JDS Questionnaires

\begin{tabular}{|c|c|c|c|c|c|c|c|c|c|c|c|c|c|c|}
\hline \multirow{2}{*}{ Companies } & \multicolumn{12}{|c|}{ Attributes for correction of the JDS questionnaire } & \multirow{2}{*}{$-\mathrm{PMT}^{*}$} & \multirow{2}{*}{$\begin{array}{l}\text { General } \\
\text { medium }\end{array}$} \\
\hline & $\mathrm{VH}$ & IT & ST & $\mathrm{AU}$ & IF & $\mathrm{EF}$ & IR & SS & $\mathrm{SC}$ & SCT & SSU & SPC & & \\
\hline FMURAKI & 5.29 & 4.70 & 5.83 & 4.72 & 4.78 & 4.87 & 6.00 & 4.71 & 5.57 & 5.63 & 5.67 & 5.51 & 121.14 & 5.29 \\
\hline AM_ENERGIA & 4.79 & 4.51 & 5.77 & 4.66 & 4.81 & 4.71 & 5.71 & 4.78 & 4.55 & 5.75 & 4.86 & 5.17 & 116.68 & 4.79 \\
\hline Medium by attributes & 5.06 & 4.61 & 5.80 & 4.69 & 4.79 & 4.79 & 5.87 & 4.74 & 5.09 & 5.68 & 5.29 & 5.35 & 119.02 & 5.06 \\
\hline
\end{tabular}

Notes. The values in the table are for each criterion and each category, the number of observations excluding non-responses; PMT—motivational potential the task, VS—variety of skills, IT—identity of the task, MT—meaning of task, AU—autonomy, IF-intrinsic feedback, EF-extrinsic feedback, IR—inter-relationship, SS—satisfaction safety, SC—satisfaction with compensation, SCT - satisfaction with coworkers, SSU—satisfaction with supervision, SPC—satisfaction with possibility of growth; Results of Fisher's test, VS: V_inter $=5.7, \mathrm{~V} \_$intra $=0.8, F=7.2, p-1=99.1 \%$, IT: V_inter $=0.5, \mathrm{~V} \_$intra $=1.1, F=0.4, p-1=48.3 \%$, MT: V_inter $=0.1$, V_intra $=1.0, F=0.1, p-1=21.3 \%$, AU: V_inter $=0.2$, V_intra $=1.1, F=0.2, p-1=30.8 \%$, IF: V_inter $=0.1$, V_intra $=0.7, F=0.1, p-1=22.8 \%$, EF: V_inter $=0.8, \mathrm{~V} \_$intra $=1.1, F=0.7, p-1=58.5 \%$, IR: V_inter $=1.7, \mathrm{~V} \_$intra $=0.7, F=$ 2.5, $p-1=88.5 \%$, SS: V_inter $=0.5, \mathrm{~V} \_$intra $=1.6, F=0.3, p-1=41.9 \%$, SC: V_inter $=17.0, \mathrm{~V} \_$intra $=1.6, F=10.7, p-1=$ 99.8\%; SCT: V_inter $=0.6, \mathrm{~V} \_$intra $=0.6, F=1.0, p-1=68.3 \%$; SSU: V_inter $=12.5$, V_intra $=1.9, F=6.6, p-1=98.8 \%$; SPC: V_inter $=2.2$, V_intra $=1.0, F=2.3, p-1=87.2 \% ;{ }^{*}$ PMT: adapted PMT $=(($ VS + IT + IR $) / 3) \times($ AU $\times$ FI $\left.)\right)$. Source: Research data.

Turning to the analysis of specific satisfactions, perceive themselves in two of the five indicators, different placements between companies. In SC, SSU, and SCT FMURAKI obtained respectively 5.57, 5.63, and 5.67, whereas with AM_ENERGIA was 4.55, 4.86, and 5.75. This indicates that aspects related to salaries and non-wage compensation, the same way that the relationship with the supervision, are best evaluated in FMURAKI. Regarding satisfaction with coworkers (SCT), indicating better assessed in the survey, both boast high satisfactory condition. Window with worse outcome in this group, for both organizations, was the SS (FMURAKI and AM_ENERGIA, 4.71 and 4.78), this time the advantage goes to the state-owned company, which has greater stability in employment and statutory consequently greater safety.

The score of the PMT varies according to Hackman and Oldham (1975), between 1 and 343 points. The parameters adopted for evaluation are framed in: "very poor" = up 102.90 points; "unsatisfactory" = 102.91 to 168.07 ; "regular" $=168.08$ to 236.67 ; "satisfactory" $=236.68$ to 305.27 , and "very satisfactory" $=305.28$ to 343.00. The results were similar to FMURAKI AM_ENERGIA reached 121.14 and 116.68. With this performance, organizations score falls within the "poor", which shows the fragility (average below 5.0) present in four of the six indicators central task.

Noting in Table 5, the correlation between the variables of the study it is noticed that in the case of PMT, there is a very strong correlation with the size of the task (0.91), i.e., the result of all the variables central explains, almost entirely, the PMT. The contextual fulfilled, in turn, have a poor correlation with the size of the task (0.11), and the variables have stronger linkages are SSU (0.85) and SPC (0.84). 
Table 5

Inter-correlation Matrix for the Study Variables

\begin{tabular}{|c|c|c|c|c|c|c|c|c|c|c|c|c|c|c|c|}
\hline & $\begin{array}{l}\text { Dimensi } \\
\text { the task }\end{array}$ & $\begin{array}{l}\text { f Contextual } \\
\text { satisfaction }\end{array}$ & PMT & $\mathrm{VH}$ & IT & ST & $\mathrm{AU}$ & FI & $\mathrm{FE}$ & IR & SS & SC & SCT & SSU & SPC \\
\hline Dimensions of the task & 1.00 & & & & & & & & & & & & & & \\
\hline Contextual satisfactions & 0.11 & 1.00 & & & & & & & & & & & & & \\
\hline PMT & 0.91 & 0.04 & 1.00 & & & & & & & & & & & & \\
\hline VH & 0.64 & 0.1 & 0.54 & 1.00 & & & & & & & & & & & \\
\hline IT & 0.34 & -0.21 & 0.29 & 0.02 & 1.00 & & & & & & & & & & \\
\hline ST & 0.45 & 0.06 & 0.46 & 0.25 & 0.02 & 1.00 & & & & & & & & & \\
\hline $\mathrm{AU}$ & 0.69 & -0.04 & 0.81 & 0.3 & 0.23 & 0.39 & 1.00 & & & & & & & & \\
\hline FI & 0.57 & 0.18 & 0.66 & 0.31 & -0.03 & 0.37 & 0.23 & 1.00 & & & & & & & \\
\hline FE & 0.63 & 0.22 & 0.43 & 0.23 & -0.09 & 0.33 & 0.27 & 0.46 & 1.00 & & & & & & \\
\hline IR & 0.48 & 0.15 & 0.31 & 0.35 & -0.11 & 0.15 & 0.21 & 0.05 & 0.19 & 1.00 & & & & & \\
\hline SS & -0.01 & 0.65 & -0.01 & -0.09 & -0.05 & 0.06 & -0.03 & 0.06 & 0.06 & 0.03 & 1.00 & & & & \\
\hline SC & 0.14 & 0.75 & -0.02 & 0.12 & -0.07 & -0.03 & -0.09 & 0.12 & 0.2 & 0.24 & 0.35 & 1.00 & & & \\
\hline SCT & 0.07 & 0.59 & 0.06 & 0.14 & -0.3 & 0.03 & 0.01 & 0.08 & 0.16 & 0.2 & 0.21 & 0.21 & 1.00 & & \\
\hline SSU & 0.08 & 0.85 & 0.05 & 0.09 & -0.19 & 0.05 & -0.06 & 0.24 & 0.21 & 0.02 & 0.34 & 0.61 & 0.41 & 1.00 & \\
\hline SPC & 0.12 & 0.84 & 0.1 & 0.15 & -0.24 & 0.14 & 0.09 & 0.16 & 0.19 & 0.1 & 0.47 & 0.45 & 0.62 & 0.67 & 1.00 \\
\hline
\end{tabular}

Notes. The values in the table are for each criterion and each category, the number of observations excluding non-responses calculated by the principal component analysis (PCA), indicating correlations (positive or negative): coef. > 0.85 (very strong); < coef. > 0.850 .70 (Strong); $0.70<$ coef. > 0.50 (average); coef. < 0.50 (weak). Source: Research data.

\section{Conclusions and Recommendations}

The two organizations were compared in order to identify, indicators of significant differences in their tax QLW, however, the study was able to prove that such anomalies cannot be considered robust. Thus, it is not possible to validate the initial proposition of research on the existence of significant differences in the indicators of QLW motivated by the type of legal personality and its task environment of organizations.

However, several factors suggest that the characteristics of FMURAKI of legal private, but acting as a service provider to public state led her to obtain indices slightly better than the public company AM_ENERGIA. The team researched the FMURAKI, unlike other organizations, demonstrates a more global perception of the task by their managers. Wages and overtime compensation and work supervisors best meet the expectations of employees, but the certainty as to the functional stability is lower, the fact that best applies to public organizations. In turn, the AM_ENERGIA displays the worst performance in its base QLW from the extent of the work. Their results show that, although there is a good relationship between colleagues, work is being seen as fragmented, with little autonomy and unmotivated.

The score of the PMT demonstrates that the weaknesses found in the size of tasks in both organizations may compromise the QLW of employees. The trend is that the combination of factors that generate positive psychological states is unsatisfactory, as it pertains to exploring the motivation and satisfaction at different levels and in different types of attitudes and behaviors (Sant'Anna et al., 2011).

Given the above, it is concluded that enterprises have more similarities than differences and stand in levels of QLW understood between "neutral" and "satisfactory", and offer a potential motivational task "unsatisfactory". The organizations surveyed sharpened sense investigative author of this article, motivating them to pursue in future research, validation and comparison of these states scores well established with other organizations. 


\section{References}

Ferreira, M. C., Alves, L., \& Tostes, N. (2009). Gestão de Qualidade de Vida no Trabalho (QVT) no Serviço Público Federal: o descompasso entre problemas e práticas gerenciais. Psicologia: Teoria e Pesquisa, 25(3), 319-327.

Hackman, J. R., \& Lawler, E. E. (1971). Employee reactions to job characteristics. Journal of Applied Psychology Monograph, 55, 259-286.

Hackman, J. R., \& Oldham, G. R. (1975). Development of the job diagnostic survey. Journal of Applied Psychology, 60(2), 159-170.

Hill, M. M., \& Hill, A. (2008). Investigações por Questionário. Lisboa: Sílabo.

Oliveira Jr., A. R. (2002). A gestão estratégica no Terceiro Setor: estudo de caso de uma organização religiosa eclesiástica no Amazonas. In F. A. Costa (Ed.), Novos Cadernos NAEA (pp. 5-87).

Sant'Anna, A. S., Kilimnik, Z. M., \& Moraes, L. F. (2011). Antecedentes, origens e evolução do movimento em torno da Qualidade de Vida no Trabalho. In A. S. Sant’Anna, \& Z. M. Kilimnik (Eds.), Qualidade de Vida no Trabalho: Abordagens e Fundamentos (pp. 3-30). Rio de Janeiro, Brasil: Elsevier.

Serra, A. C. (2006). Indicadores de Qualidade de Vida no Trabalho: um estudo comparativo entre o corpo docente de instituições públicas e privadas de Moçambique (Dissertação de Mestrado, Instituto Superior Politécnico e Universitário, Centro de Pós-Graduação e Pesquisa Aplicada. Maputo: Instituto Superior Politécnico e Universitário).

Vasconcelos, A. F. (2001). Qualidade de Vida no Trabalho: Origem, evolução e perspectivas. REGE-Revista de Gestão, 8(1), 23-35.

Yin, R. K. (2010). Estudo de Caso: Planejamento e métodos (4th ed.). Porto Alegre: Bookman. 